\title{
Throw It Overboard: A Commentary on Coastal Pollution and Bioremediation
}

\author{
Roger H. Charlier ${ }^{\dagger \dagger}$, Charles W. Finkl ${ }^{\ddagger}$, and Agata Krystosyk-Gromadzinska ${ }^{\S}$ \\ ${ }^{\dagger}$ Free University of Brussels \\ (Vrije Universiteit Brussel) \\ Brussels, Belgium \\ Department of Geosciences \\ Florida Atlantic University \\ Boca Raton, FL 33431, USA \\ cfinkl@cerf-jcr.com \\ ${ }^{\S}$ West Pomeranian Technical University \\ Szczecin, Poland
}

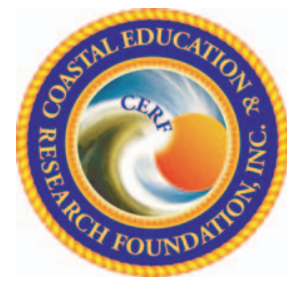

www.cerf-jcr.org

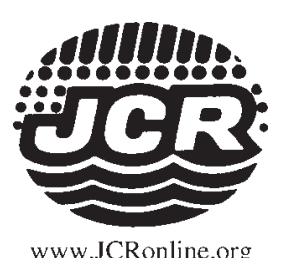

www.JCRonline.org

\begin{abstract}
Charlier, R.H.; Finkl, C.W., and Krystosyk-Gromadzinska, A. 2012. Throw it Overboard: A Commentary on Coastal Pollution and Bioremediation. Journal of Coastal Research, 28(4), 881-890. West Palm Beach (Florida), ISSN 0749-0208.

The belief that rivers and oceans cleaned themselves faded as humanity expanded and wastes took on an ever more diversified character. The pollution of waterways, bays, inlets, and gulfs made many of them unusable for water transport. The solution commonly applied is to dredge, an expensive approach but also one that de facto substitutes land pollution for water pollution. Availability of land is not limitless either. Hence, in situ bioremediation is gathering an increasing number of adepts. Alleviating damages caused by green tides and cleaning up waterways, estuaries, inlets, and bays are continuous coastal and river concerns that have been variously approached. This paper reviews and summarizes several experiments. Treatment of sludge is necessitated, over several decades, by the diminishing space on land to deposit the dredgings, but also by the need to protect human and subsidiarily animal and plant health. Substantial advances have been made in the area of bioremediation including, but not limited to, the hydrological realm. Nevertheless, some frequently occurring compounds remain recalcitrant. Pilot projects have been conducted for some time in the United States and European countries.
\end{abstract}

ADDITIONAL INDEX WORDS: Eutrophication, bioremediation, socioeconomic impact, Ulva sp., Hudson and Sheboygan rivers, Moervaart and Zierikzee, $P A H, P C B$.

\section{INTRODUCTION}

Armand Charlier, the father of the coauthor of this paper, was a civil servant in the Departments of Population, Tourism, and Public Health of the port city of Antwerp. He was also on the local level a noted acid-penned reporter. All the activities were linked. Notwithstanding the then-traditional 6-day workweek, he did not always sleep late and recuperate on Sunday morning, but managed occasionally to take his son on boat rides. As any child, no sooner were they aboard that the little boy had to answer Nature's call and returned puzzled and upset to his father: the toilet had no bottom and urine was actually poured into river or sea. Similarly garbage was thrown overboard by the mariners, for the greater joy of seagulls. Wasn't this dirtying the waters?

"Moving waters clean themselves" came the answer. Perhaps then, but pollution was well on its way. Rivers were used as sewers. Even some docks were so polluted that Senten, in his thesis, reported 30 years ago that one basin in Antwerp had its waters coalesced to the point that some boats could not be moved anymore (Senten, J.R., doctoral thesis at the Faculty of Sciences of the Vrije Universiteit Brussel). Today, much is still thrown overboard, leading to black tides. Directly or indirectly

DOI: $10.2112 / 11 A-00020.1$ received and accepted in revision 15 July 2011.

Published Pre-print online 13 February 2012.

(c) Coastal Education \& Research Foundation 2012 humans are responsible for the variously "colored" tides of ocean and sea: black tides, red tides, green tides....

The Mediterranean Sea has been said to be the waste bin of its riparian states. The Baltic Sea is badly contaminated. The North Sea, south of Sweden, has an accumulation area where wastes pile up. The oceans have two major areas free of marine currents where pollutants end up, particularly plastics. These substances cause a large number of illnesses and deaths among marine animals. The matter was brought up at the 2011 meeting of the International Whaling Commission. The same substances are also the cause of motor failures in smaller ships. Hard to grasp, but these two oceanic spots have wastes that cover areas twice as large as the United States. This, of course, does not include sunken vessels and dumped obsolete military hardware. Closer to the coasts other pollution problems plague those responsible for tourism: green tides.

\section{The Algal Plague}

The sources of these wastes vary widely, ranging from illegal dumping actions by ships whose captains wish to avoid the fees charged by appropriate shore facilities to runoffs from bordering lands, materials carried by rivers and willful ignorance from rules, regulations, and respect for the environment. Facts are disclosed in the OSPAR-2007 report. Cleaning up the oceans represents, evidently, a pharaonic task. Regional efforts could very well be worthwhile. 


\section{Algae on French and Florida Coasts}

The U.S. House Subcommittee on Energy and Environment held hearings to examine harmful algal blooms (HABs) and hypoxia on June 2, 2011. Specifically, the hearings looked at research needs to develop and implement action plans to monitor, prevent, mitigate, and control both marine and freshwater bloom and hypoxia events. According to the National Oceanic and Atmospheric Administration, HABs and hypoxia have an annual negative economic impact of $\$ 82$ million ( $€ 55$ million) in the United States.

Green tides carry dire economic consequences, particularly for tourism. Proliferation of algae, especially Ulvae, along the coasts of Brittany and some areas of southwest Florida, have seriously damaged large segments of the tourism areas in those regions. The problem has also affected with considerable intensity regions of Italy, for instance in Orbitello. Already, more than two decades elapsed since the European Commission sponsored conferences and publications dealing with the matter. Removal of the stranded material is a costly process and disposal is an additional one. Quantities are so large that utilization of the algae is hardly possible, and the dumping inland creates a subsequent land pollution. Methanization as a solution has been repeatedly proposed. Successful methods have been developed at a Centre National de la Recherche Scientifique laboratory of the University of Rennes 1 (France). ${ }^{1}$

The European Union encouraged the assessment of seaweed resources, and even their cultivation, and yet, simultaneously and contradictorily, it had to consider the natural proliferation of the algae as a nuisance. As algae are tolerant of a wide range of salinity, temperature, light, and pollution, they spread easily and survive.

The negative effects of eutrophication include ailments and mortality of flora and benthic and pelagic fishes, not sparing marine farms; atmospheric discharge of sulfur compounds by bacteria that decompose organic matter of algal origin; compounds in part responsible for acid rain; heavy beach pollution due to strandings; and economic stress for communities that must remove the material and dispose of it.

Agriculture and draining of wetlands are major agents in causing eutrophication. Exceptional blooms, the algal proliferations that are harmful for humans, are linked to eutrophication, hydrodynamics, and climate, viz. weather conditions. An extreme example has been the Lake of Tunis, site of extreme eutrophication during summer months: in calm weather the entire water column occasionally becomes anaerobic.

\section{FRANCE'S ATLANTIC COAST}

Studying eutrophication along the French Atlantic coasts, Briand (1987, 1989) established already a quarter of a century ago that green algae that particularly proliferated were mostly Ulva, Enteromorpha, and Cladophora; among the red algae

\footnotetext{
${ }^{1}$ Charlier, R.H.; Morand, P.; Finkl, C.W., and Thys, A.C., 2009. Green tides on the Brittany coasts. In: Zhang Hui-rong, (ed.), Enteromorpha prolifera (Müller) [J. Agardh ecology research] [In Chinese.] Beijing: Ocean Press, pp. 35-43.
}

Gracilaria and Porphyra. ${ }^{2}$ The culprits for eutrophication in Brittany are said to be domestic and industrial wastes' nutrients carried by streams and waterways, leaching of fertilized soil by rainwater, nutrients of atmospheric origin contained in rainwater, nitrogen fixation by blue-green algae or cyanobacteria, and nutrients from artificial ponds such as food surplus and fish excreta.

The allocation, for 2010, by France of $€ 700,000$ to combat the green tides plague was more than was expected to be needed because pollution due to algae has substantially been reduced. Causes? The long and harsh 2009-2010 winter. With water temperatures at $-10^{\circ} \mathrm{C}$, algae were dispersed far offshore; next the gathering of stranded algae in 2009 and the climategenerated drop in river discharge led to a lesser runoff of pesticides' $\mathrm{NO}^{3}$. Reduction of quantity of stranded algae was especially recorded in St. Brieuc Bay and Fresnaye Bay (from St. Cast le Guildo to Fréhel).

In some areas (e.g., the Lannion region) pickups were even cancelled. Funds had been earmarked for $25,000 \mathrm{~m}^{3}$ and only $1 \mathrm{mg} / \mathrm{l}$ of water was not reached. Principal source of this information was the French daily Le Monde. ${ }^{3}$ Good news proved to be only a short respite because by June 2011 the bulldozers were back on the beaches scooping up tons of stranded algae.

Some studies have concluded that algae, a scourge by themselves, can, under certain circumstances, be water purification agents, and so can some oysters, whereas shrimp (Crangon crangon L.) play the part of water quality indicators. ${ }^{4}$

\section{THE AERATION APPROACH}

The problem of coastal water and waterway pollution reaching unacceptable dimensions is of course geographically widespread. The Venice Lagoon is a classical case and various approaches to the problem have been proposed. Aeration has been suggested as described hereafter.

Sediments in industrialized or urbanized coastal shallow waters have thus reached an alarming and harmful level of contamination, demanding development of new cost-effective technologies. An in situ forced aeration experiment was conducted in Venice, Italy in the Arsenale shipyard dock basin of the Venice Lagoon. A similar experiment carried out in the Industrial Harbor of Marghera, where sediment reworking and mixing are strong, provided promising results.

However, at the Arsenale shipyard site a new forced aeration system was tested; it aimed at oxygenating the surficial sediments with a minimum of reworking and mixing. The aeration technique, chosen for the oxygenation of the highly

\footnotetext{
${ }^{2}$ Brault, D.; Briand, X., \& Golven, P., 1985. Les marées vertes. In: Bases biologiques de l'aquaculture: Colloque de Montpelier 1983, Actes, IFREMER I, pp. 33-43; Briand, X., 1989, Doctoral thesis, Paris; Briand, X. \& Morand, P., 1987. Ulva stranded algae. In: Grazi, G. et al. (ed.), Proceedings of the. 4th European Conference on Biomass for Energy and Industry, Orléans; Charlier, R.H., 1991. Algaeresource or scourge. Part II: economics and environment: International Journal of Environmental Studies 8, 237-250.

${ }^{3}$ Issue of the last Friday of September 2010.

${ }^{4}$ Charlier, R.H.; Finkl, C.W.; Morand, P., and Thys, A.C., 2009.
} 
polluted bottom sediments, is unique because of its innovative ${ }^{5}$ use of a system of porous pipes laid on the bottom sediments; thence it is nonintrusive and has the added advantage not to obstruct harbour activities.

Forced aeration consists of the introduction of a large quantity of oxygen at the surficial sediment-water column interface so that aerobic bacterial communities are timulated to create an adapted environment for the biodegradation of organic and inorganic pollutants. The general reduction of organic pollutants and heavy metals in the surficial sediments resulted in the documented return of small fish to the area as an indication of a less polluted environment.

The experiment showed that tangential forced aeration could represent a nonintrusive and cost-effective way to reduce organic and heavy-metal pollutants in coastal environments, wherein other techniques may not be environmentally or economically feasible. ${ }^{6}$

\section{THE OYSTER AS PURIFICATION AGENT}

The Eastern oyster, Crassostrea virginica, may improve water quality by filtering large quantities of particulate matter (both organic and inorganic) and nutrients from the overlying water column. Additionally, oyster reefs alter hydrodynamic conditions, further increasing the removal of particulate matter from the water column. A recent study examined the effects of small-scale oyster additions on sediment loading, chlorophyll $a$, nutrient concentrations, and flow in small tidal creeks. Two reefs were established in Hewletts Creek, New Hanover County, North Carolina. Total suspended solids (TSS), chlorophyll $a$, and ammonium were measured upstream and downstream of each created reef and in an adjacent control channel that lacked a reef.

Data were collected monthly during ebb tides over a 10-month period between September 2000 and June 2001. In the first month after initial reef placement, mean TSS concentrations downstream of reef placement were slightly lower than those upstream of the reef. Although not statistically significant, TSS concentrations downstream of the reefs were less than upstream concentrations for five of nine and five of seven postreef sampling months for the upland and the lower creek sites, respectively. Chlorophyll $a$ concentrations were not significantly affected by initial reef placement $(2 \times 3 \mathrm{~m})$, but were reduced substantially after reef enlargement $(3 \times 4 \mathrm{~m})$ in one of the experimental creeks. Reef placement resulted in significant increases in ammonium concentrations downstream of the transplantedreefs. In addition, deposition of feces and pseudofeces by the oysters resulted in accumulation of finer-grained materials in the treated channel relative to the control channels.

Oyster filtration was most effective 3 hours after high tide, when the ratio of flow discharge to reef surface area was the highest. This work demonstrates that small oyster reefs

\footnotetext{
${ }^{5}$ Bonardi, M.; Ravagnan, G.; Stirling, J.A.R.; Morucchio, C., and De Sanctis, S., 2007. Innovative treatment by bioremediation of contaminated sediments from the Venice Lagoon, Italy: the Arsenale Vecchio case study. Journal of Coastal Research, Special Issue No. 50 (Proceedings of the 9th International Coastal Symposium, Gold Coast, Australia), pp. 895-899.

${ }^{6}$ Bioremediation of Sediments. Dolloff F. Bishop (see footnote 8).
}

established and maintained in some small tributary channels can reduce TSS and chlorophyll $a$ concentrations and that the magnitude of the effect may vary over the course of the tidal cycle. ${ }^{7}$

\section{BIOREMEDIATION IN SITU}

Some 20 years ago at a PIANC ${ }^{i}$ meeting in Djakarta, Indonesia, the chief executive officer of a dredging company nearly became apoplectic when a paper suggested substituting, at least in part, bioremediation of sludge for the onerous and expensive traditional process-dredging — that was his and kindred enterprises' bonanza. The paper ${ }^{i i}$ nevertheless gathered audience enthusiasm and was awarded distinction and a prize.

Indeed, realistically considering use of expensive and ever scarcer land space, a solution had to be found to dispose of the materials dredged from waterways-rivers, canals, bays, ports, and coastal areas. Dumping at sea had already then been shown to be ecologically very unwise. These authors, ${ }^{i i i}$ among many others, published findings and proposed potential solutions to the dilemma.

In situ natural microbiological degradation of organic matter and compounds may offer a remedy to the problem. For decades Thierry Lebeau, for instance, has tackled the problem and multiplied laboratory and field studies. If research is usually directed at soils, ${ }^{\text {iv }}$ extension to the riverine, estuarine, and marine domains is an evident corollary. In the works listed in the footnote, conclusions reached go beyond agricultural science, in that the choice of microorganism(s) for the inoculation of contaminated soils depends on the cadmium level in the medium and on the distribution of the metal between the biomass and the medium. Microalgal cell immobilization may be a suitable technique for application to benthic diatoms; these are usually sensitive to bioturbation or metabolites, which may be overemphasized. Furthermore the cell immobilization techniques allow benthic diatoms to be cultivated more efficiently, permitting new biotechnologically relevant products to be investigated.

Contaminated sediments in rivers, lakes, and harbours not only pose a burden to navigation and economic exploitation of harbours, they constitute a serious risk to human health and the environment. Destruction of contaminants in sediments can be attained through natural attenuation and can be improved by natural processes involving microbial growth and enzymatic production, because bioremediation can convert target contaminants to nontoxic end products. This is not a miracle process, as, for instance, polychlorinated biphenyls (PCBs) and polynuclear aromatic hydrocarbons (PAHs) biodegrade only slowly and bioaccumulate up the food chain..$^{\mathrm{N}}$ Both PCBs and PAHs are biodegradable under appropriate conditions in laboratory studies. The latter degrade under aerobic conditions. PCBs degrade under both anaerobic and aerobic conditions.

\footnotetext{
${ }^{7}$ Nelson, K.A., Leonard, L.A., Posey, M.H., Alphin, T.D. and Mallin, M.A., 2010, Crassostrea as purification factor: Center for Marine Science, University of North Carolina at Wilmington, 5600 Marvin K. Moss Lane, Wilmington, NC 28409, USA.
} 


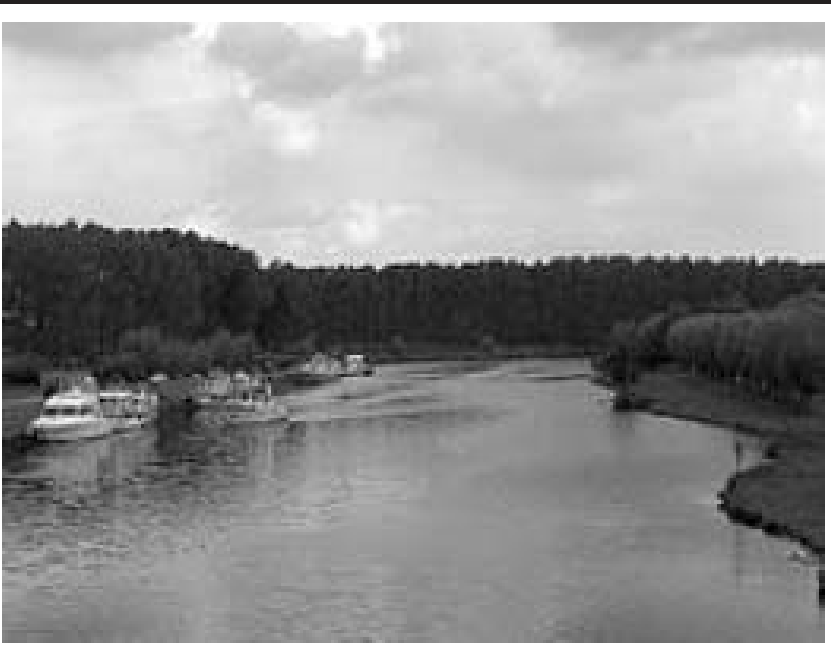

Figure 1. The Moervaart in East Flanders, Belgium.

Bishop ${ }^{8}$ found that persistent contaminants in sediments are resistant to microbial degradation because of contaminant toxicity to the microorganisms, preferential feeding of microorganisms on other substrates, their inability to use a compound as a source of carbon and energy, unfavourable environmental conditions in sediments for their propagation, and poor contaminant bioavailability to microorganisms.

Bioremediation has been tried in the Netherlands, for instance at Zierickzee, and in Belgium, for instance on the Moervaart. ${ }^{9}$ This waterway (Figures 1 and 2) was at one time an important transportation link but has been for some decades rather a pleasure-craft and watersports water expanse.

Successful bioremediation of sediments requires combining appropriate microbial pathways, biochemistry, and the function of natural microbial communities with innovative engineering methods to overcome the recalcitrance of the compounds in sediments, thus increasing bioremediation effectiveness. Sediment dredging offers the opportunity for alternative ex situ treatment such as biotreatment in confined treatment facilities, slurry reactors, and composting land treatment applications. ${ }^{\text {vi }}$ Slurry reactor technology has also been applied in situ to contaminated sediments in water bodies (5).

Studies have been conducted and results assessed for waterways in the Netherlands and close to its border in Belgium (Moervaart) and results compared with field studies in Sheboygan (Wisconsin, USA) and the Hudson River (New York), where testing in New York as well as in California of the conditioning in situ (CIS) approach has been under consideration. Along the Belgian coast (Zeebrugge) bioremediation has also been used. Assuming contaminants in sediments or sludge

\footnotetext{
${ }^{8}$ Bishop, D.F., 2010. Bioremediation of sediments, Seminar Series on Bioremediation of Hazardous Waste Sites: Practical Approaches to Implementation, pp. 3-1, 3-2-3-6.

${ }^{9}$ The Moervaart at one time was a major waterway for the transport of peat, and during Spanish domination of the Lowlands, a communication channel for the Spanish navy.
}

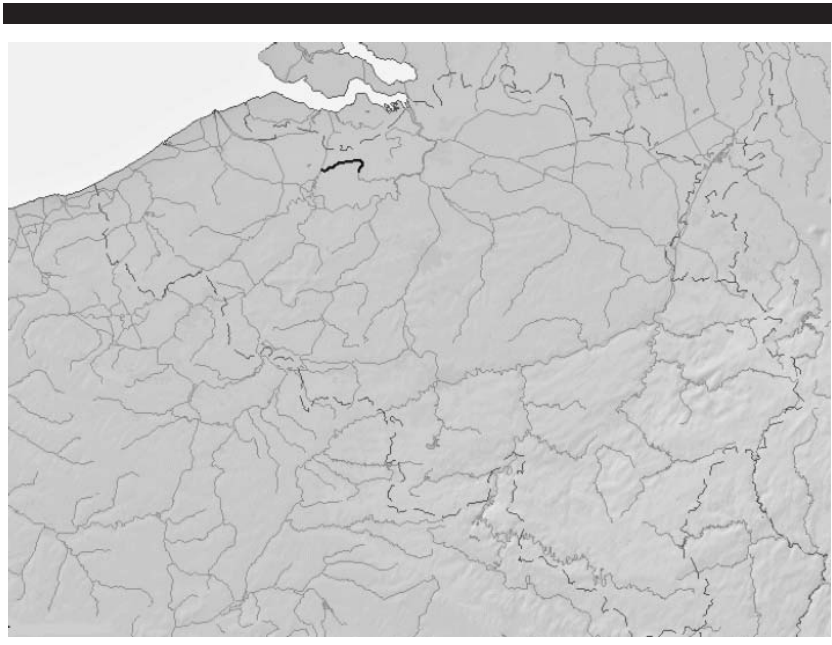

Figure 2. The Moervaart, close to the Ghent-Terneuzen sea canal. The waterway is dark colored on the map (top left of center).

are the commonly found types, one can expect natural attenuation to occur, a process to be enhanced by bioremediation using amendments. Microbial growth and enzymatic production is often limited by conditions in sediments, whereas PCBs and PAHs will be encountered as common highmolecular-weight contaminants. Bioremediation of marine and freshwater sediments will be slowed-even limited-by contaminant(s)' toxicity to microorganisms, their preferential feeding on other substrates, and inability of microorganisms to use contaminants; furthermore, sediment(s)' conditions may be unfavorable for an appropriate microbial propagation and under some circumstances contaminants may not be available to the microorganisms.

Achieving successful bioremedial results requires the combination of appropriate microbial pathways, appropriate biochemistry, and functionality of natural microbial communities; also needed are the development of innovative engineering methods in sediments to overcome contaminant recalcitrance to biodegradation, in situ biotreatment without reactors, in situ treatment of dredged sediments for enhanced bioremediation, and in situ biotreatment with slurry reactors in water bodies.

\section{REHABILITATION OF BAYS AND WATERWAYS}

Bays, inlets, and especially, waterways are dredged to maintain navigation channels, but some are being virtually used as open sewers and need to be cleaned up. In harbors, basins are recipients of a variety of materials, not infrequently with a high concentration of heavy metals. In Thailand, a problem has emerged around temples in whose waters "holy turtles" could benefit from a cleaner environment! Dredged materials often release foul odors and, worse, their disposal constitutes a major problem as land space is at a premium and ocean dumping is mostly prohibited, though press releases point to the possibility of resumption of the practice.

All dredged material is not, however, necessarily severely polluted; sludge should be considered separately; there are 
several methods of treating sediments. ${ }^{10}$ Nevertheless, major European rivers (Rhine, Meuse, Elbe, Seine) are badly polluted. The Danube, in Vienna, hardly deserves Strauss' waltz "The Beautiful Blue Danube"! Treatment is advocated, storage is suggested, use is urged, and pollution containment is called upon.

Among treatment methods, bioremediation is frequently proposed as an approach holding promise. In the United States, besides in the Sheboygan (Wisconsin) and Hudson (New York) rivers, technologies were tested, on a pilot scale, under the "Assessment and Remediation of Contaminated Sediments" program of the U.S. Environmental Protection Agency on American Great Lakes sediments; they included thermal desorption, solvent extraction, washing, and bioremediation.

\section{DISPOSAL AND TREATMENT OF DREDGED MATERIAL}

\section{Disposal}

Dredged material can be disposed of either on land or in waters.

For strongly contaminated sediments, special treatment is sometimes necessary.

\subsection{Land and Marine Disposal}

Land disposal must be used for moderately to heavily contaminated sediments. Special care is needed for the evacuation of water and for diffusive and dispersive transport.

Alternatives for disposal on land are:

- Uncontrolled dumping.

- Uncontrolled disposal, e.g., on agricultural land. Besides the low level of pollutants and the presence of major elements $(\mathrm{N}, \mathrm{P}, \mathrm{K}, \mathrm{Ca}$, and $\mathrm{Mg}$ ), the soil must have an optimum $\mathrm{pH}$ and cation-exchange capacity and contain sufficient amounts of organic matter. $^{2}$

- Disposal of dried dredged material in a controlled dumping site, with or without capping. The site can be confined with either natural, e.g., clay, bentonite, or materials such as polyethylene or polyvinyl chloride or a combination of both.

- Aquatic disposal. ${ }^{3}$

1.2. Disposal in situ in zones confined by boundary structures or in burrow pits (with or without capping).

Land and aquatic disposal always require an environmental impact assessment. Direct and indirect effects, both short and long term, of the dredged material and the runoff water on fauna, flora, groundwater, water column, soil, and air quality have to be investigated.

\footnotetext{
${ }^{10}$ See sampling of research and symposia focusing on these specific problems in bibliographic Appendix I.
}

\section{Treatment of Contaminated Dredged Material}

Contaminated dredged material sometimes needs to undergo physical/chemical treatment. As most heavy metals are concentrated in the $<20-\mu \mathrm{m}$ fraction, a separation of the coarse fraction is a first step to obtain a product with an acceptable content of pollutants. This can be performed in a hydrocyclone (separation of fine/coarse material on the basis of centrifugal force), followed eventually by processing in an elutriator where separation is achieved by the settling of particles in an upflowing water stream.

The dewatering step reduces the contaminated dredged sediment to about $1 / 4$ or less of the original volume and concentrates the major part of heavy metals and other pollutants in the remaining particulate matter. More contaminated material such as the fine fraction of the hydrocyclone and elutriator needs special chemical treatment, e.g., acid leaching and separation of solubilized heavy metals with an ion exchanger.

Another currently developed technique is the biological oxidation of sulfur compounds present in the sludge into sulfuric acid by Thiobacillum organisms and the subsequent extraction of heavy metals as sulfates, lead not being removable because of formation of insoluble lead sulfate.

\section{Motivation}

Dredging is a costly and recurrent operation. Spoils must be disposed of and their use in beach maintenance or renovation is linked to the possibility that quantities exceed utilization possibilities and that their composition may pose pollution dilemmas.

Deposits in aqua systems may promote an accumulation of organic micropollutants; large nitrogen and phosphorus runoffs into streams, rivers, and, eventually, the sea1 and bays give rise to eutrophication and such ensuing blooms as green tides. Likewise, heavy metals often concentrate in dock- and harbor-basin sediments.

The self-cleansing capability of river and marine systems has been frequently mentioned; however, it has probably been overestimated, and certainly overtaxed. Obviously there is no alternative but to remove accumulated "sediments" frequently grouped under the generic terms of "mud" or "sludge".

Cleaning of dredgings before acceptable disposal is costly, not entirely efficient, time consuming, and commonly releases foul odours. Opposition of people to processing facilities is consequently understandable, thence the need to devise an odorless technique and compacting the volume because the handling and the immobilisation techniques shift the problem, rather than solve it. Traditional treatment technologies are unsatisfactory because of the sheer volume involved and of economics. ${ }^{4}$

\section{NATURE'S APPROACH}

It appears indicated to follow nature's approach. Microbiological methods tackle the existing problems at their base and bacteriological activity will eradicate pollutants. The augmented bioreclamation/conditioning in situ $\left(\mathrm{ABR} / \mathrm{CIS}^{T M}\right)$ - is a method 
Table 1. Contaminants' bioremediation and limitations of the process (after D.A. Bishop).

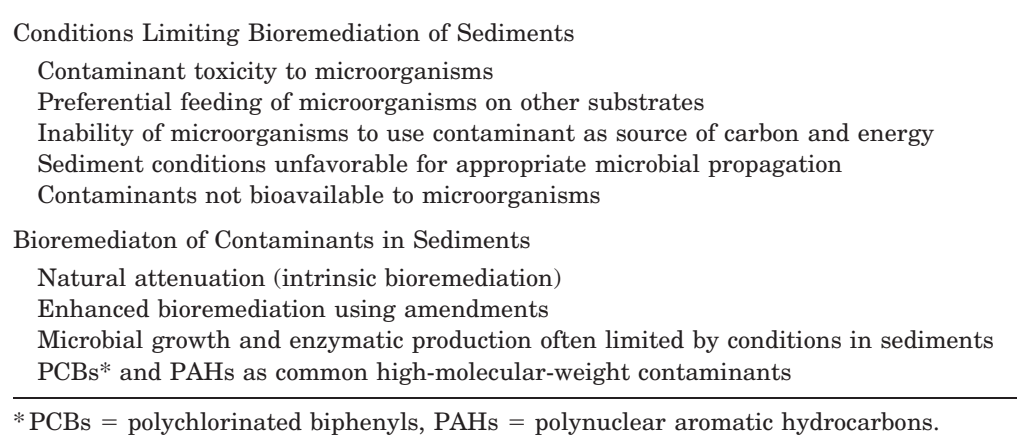

designed for the in situ treatment of specific subaquatic bottoms that relates to one or more effects. The effects at hand are:

- Mud volume reduction through mineralization of organic components. The transformation of carbon dioxide into water is referred to as microbiological dredging;

- Mineralization of environmentally objectionable organic pollutants;

- Cleansing of the subaquatic bottom and the overriding water column through an improved oxygen-economy;

- Abatement of foul smells due to anaerobic fermentation through an improved aerobic breakup.

The ABR/CIS is designed for the in situ remediation of organic muds or muds contaminated with organic micropollutants.

\section{CIS, AN IN SITU APPROACH}

To achieve successful biodegradation, as many aerobic bacterial strains as possible should be reactivated in situ, an approach with an additional benefit: not only are organic containments removed, but volume of the deposit is simultaneously reduced, allowing reclamation of polluted areas.

Mud habitats are the sites of decaying biomass, absorbed organic compounds, nutrients, and man-contributed contaminants. Bacteria play a major role in organic matter mineralization in water column and underlying sediments. The oversupply of organic materials, among others, stymie natural biodegradation. Adding to the oxygen supply may reactivate aerobic mineralization of organic matter and of some organic micropollutants. In fact bioremediation may contribute to cleaning the marine domain. Environmental changes and man-caused stresses affect dynamics and structure of marine ecosystems.

The CIS or BIO-C process is a georemediation conditioning applied in situ. A first step is the identification and subsequent isolation of microorganisms from the sediment, a procedure proper to each individual project. These microorganisms are then cultivated on carbon sources similar to the target contaminants to be treated; microbiological proliferation is monitored for oxygen uptake and total or selective plate counts.

Upon confirmation of mud treatability, remediation treatment is designed, to wit dosage, bacteria type, and injection scheme. Included in the process is the culture of microorganisms, blending of the conditions, mixing with bran fibers, and eventual transport of the obtained ground power to the utilization site. Next steps are dilution and aeration over a 24-hour period with water of the waterway or bay or inlet concerned that provides the suspension to be injected into the sediment. The latter operation is done with specially adapted dredging equipment or pressure jetting. Sediment level and quality are constantly monitored.

A dozen pilot projects seemed to indicate the efficiency of the method, when a first full-scale project involved a port on the canal skirting the Dutch city of Zierikzee, where waters were organically polluted by the large discharges of atmospheric washed precipitations and city domestic effluents. Involved were a $15-\mathrm{m}$-wide 3 -km-long canal and a mud layer of up to more than $1 \mathrm{~m}$ thick. The sludge was made up of $14 \%$ dry matter, $22 \%$ dry organic matter, and a $<2$-m-thick fraction representing a mean $32 \%$.

Six microorganisms were cultured: Pseudomonas putida, $P$. aeruginosa, P. fluorescens, Bacillus subtilis, B. licheniformis, and Escherichia hermanii. Results to be underscored are significant degradation of mineral oils and promising evolution of organic pollutant breakup degradation of PAH, Dibenzene, and anthracene.

Bioremediation was tried in the Netherlands, among other sites, at Zierikzee, and in Belgium, for instance on the Moervaart. This waterway (Figures 1 and 2) was at one time an important transportation link but has been for some decades rather a pleasure-craft and watersports water expanse.

Contaminated sediments in rivers, lakes, and harbours pose a potential risk to human health and the environment. Bioremediation, through natural (intrinsic) attenuation and through enhanced bioremediation, promises possible approaches for destruction of contaminants in sediments. Using natural processes involving microbial growth and enzymatic production, bioremediation can convert target contaminants ultimately to nontoxic end products.

High-molecular-weight contaminants, however, such as PCBs and PAHs, persist in sediments, biodegrading only slowly while strongly partitioning to the sediments and bioaccumulating up the food chain, in time reaching humans. PCBs are typically degraded under sequential anaerobic and aerobic conditions and PAHs are typically degraded under aerobic conditions. Appropriate anaerobic conditions dehalogenate more highly chlorinated PCBs, usually the meta- and parachlorines on the biphenyl structure.

Persistent contaminants in sediments resist microbial degradation because of contaminant toxicity to the microor- 
ganisms, preferential feeding of microorganisms on other substrates, microorganisms' inability to use a compound as a source of carbon and energy, unfavorable environmental conditions in sediments for propagation of appropriate microorganisms, and poor contaminant bioavailability to microorganisms (Table 1).

Try-outs have been carried out in the Hudson and Sheboygan rivers. Though not plethoric, a rather abundant literature describes the two projects. ${ }^{11}$

\footnotetext{
${ }^{11}$ Aartila, T. 1996. Sheboygan River invertebrate community assessment: indicators of polychlorinated biphenyl contaminated sediments. Wisconsin Department of Natural Resources, Southeast District. Draft for review only. January 31, 1996.

Blasland, Bouck, \& Lee, Inc. 1995. Alternative specific remedial investigation report, Sheboygan River and Harbor. Volumes 1-4. Syracuse, New York.

Blasland, Bouck, \& Lee, Inc. 1996. Work plan/QAPP, interim monitoring program, Sheboygan River and Harbor. Syracuse, New York.

Blasland, Bouck, \& Lee, Inc. 1998. Feasibility study report, Sheboygan River and Harbor site, Sheboygan, Wisconsin. Syracuse, New York.

Burzynski, M. 2000. Sheboygan River food chain and sediment contaminant assessment. Final project report U.S. EPA Grant \#GL995681. http://www.epa.gov/glnpo/sediment/FoodChain/index.html

Bzdusek, P.A.; J. Lu, and E.R. Christensen. 2005. Evidence of finegrained sediment transport and deposition in Sheboygan River, Wisconsin, based on sediment core chemical tracer profiles. Water Resources Research, 41.
}

Chapman, J. 1997. Sheboygan River and Harbor Superfund site floodplain soil and earthworm field sampling plan. Prepared for U.S. Environmental Protection Agency.

Chapman, J., 1999. Sheboygan River and Harbor floodplain terrestrial ecological risk assessment. Prepared for U.S. Environmental Protection Agency.

Eggold, B.T.; J.F. Amrhein, and M.A. Coshun, 1996. PCB accumulation by salmonine smolts and adults in Lake Michigan and its tributaries and its effect on stocking policies. Journal of Great Lakes Research, 22(2), 403-413.

Environ, 1995. Risk assessment for the Sheboygan River, Sheboygan County, Wisconsin. Environ Corporation, Princeton, NJ.

Jones, W.J.; R. Araujo, and J.E. Rogers, 1996. Bench-scale evaluation of bioremediation for the treatment of sediments from the Ashtabula, Buffalo, Saginaw and Sheboygan Rivers, final report. Ecosystems Research Division, National Exposure Research Laboratory, U.S. Environmental Protection Agency, Athens, GA. http://www. epa.gov/glnpo/arcs/r96012/r96012.html

Li, J.; M.K. Mgonella; P.A. Bzdusek, and E.R. Christensen, 2005. PCB congeners and dechlorination in sediments of Upper Sheboygan River, Wisconsin. Journal of Great Lakes Research, 31(2),174-186.

Lu, J.; P.A. Bzdusek; E.R. Christensen, and S. Arora, 2005. Estimating sources of PAHs in sediments of the Sheboygan River, Wisconsin, by a chemical mass balance model. Journal of Great Lakes Research, 31(4), 456-465.

Patnode, K.A.; B.L. Bodenstein, and R.R. Hetzel. 1998. Using tree swallows to monitor impacts of aquatic contamination in Great Lakes Areas of Concern. Professional meeting Poster session presentation report. Wisconsin Department of Natural Resources, Madison, Wisconsin.

Sonzogni, W.C., 1990. PCB dechlorination in the Sheboygan River, Wisconsin. Extended abstract prepared for a workshop on Biological Remediation of Contaminated Sediments, July 17-19.

Sonzogni, W.; L. Maack; T. Gibson, and J. Lawrence, 1991. Toxic polychlorinated biphenyl congeners in Sheboygan River (USA) sediments. Bulletin of Environmental Contamination and Toxicology, 47, 398-405.

Szumski, M.J. 1996. Mink radio-telemetry and abundance studies on the Sheboygan and North Fork of the Milwaukee Rivers. Draft annual report.

\section{CONDITIONING IN SITU}

Appropriate conditioning in situ using natural oxygensupplying products may, in specific instances, reactivate aerobic mineralization of organic matter, even some organic micropollutants. The potential value of CIS encompasses thus microbiological dredging and treatment in situ.

Mud habitats are home to decaying biomass, absorbed organic compounds, various nutrients, and anthropogenic contributed contaminants. In the water column and the underlying sediment, bacteria play a major role in organic matter mineralization.

Texture, temperature, oxygen content, contaminants absorbed by mineral or organic mud particles, or bacteria aimed toxicity to other seasonally cycled organisms.

Adaptability is governed by such growth factors as presence of oxygen, nitrates, phosphates, and sulfates. Once biodegradation has set in, hydrogen sulfide, ammonium, nitrogen, carbon dioxide, and water thus formed are released back into the water column and the atmosphere. To assimilate carbonic acid-the basis of bacteria's metabolismby resorption through cell membrane, bacteria secrete selective and species-specific exoenzymes that act as biocatalysts, enabling decomposition and mineralization of a wide range of organic compounds, e.g., emmic acids, phenols, mineral oils.

Seasonal variations have an impact on bacteria: protective mechanisms include spore and dwarf cell formation, as well as "hibernation". To improve the required environmental conditions, bacteria secrete fibers to adhere to sediment particles or organisms, or they may join to form chains. Their life spans range from months to years.

Oxygen supply in muds decreases with sediment thickness, and bacterial activity is per se mostly anaerobic, resulting in slow and incomplete organic matter degradation. Surface-layer bacteria are principally Pseudomonas, Vibrio (both gram-negative bacilli), Nitrosomonas, and Nitrobacter (autotrophic nitrificators). Diatoms and blue algae also thrive here. Mud is the site of intense bacterial proliferation, organic matter decomposition, and organic carbon mineralization.

Where aerobic species cannot thrive any longer, respiration is anaerobic, or fermentative processes come into line, Fenobacteria occur at all levels. Clostridium can mineralize organic matter and synthesize exoenzymes capable of hydrolyzing assimilable macro- into micromolecules.

Bacteria are denitrification agents by catabolic reduction or catabolic fermentation. Some reduce sulfates, an important process in anoxic marine deposits for organic matter mineralization; the reaction causes the typical "rotten eggs" smell (hydrogen sulfide). Finally, specific bacteria reduce the bicarbonate molecule at very low redox potential values to methane.

Anaerobic mineralization processes are slow and have a low efficiency, resulting in a slow biodegradation of accumulated organic matter and foul odors. Aerobic processes, however, are fast and more efficient because of increased metabolism. CIS provides bioavailable oxygen disseminated in the sediment, stimulating the aerobic biodegradation processes. 


\section{AUGMENTED BIORECLAMATION}

The ABR technology uses already present microorganisms that spontaneously undertake the breakdown of organic impurities. The purpose of $\mathrm{ABR}$ is to accelerate the natural processes and to aim and direct them. Pollutants are, in nature, broken up stepwise and the basic molecule is gradually reduced to ever smaller elements or "radicals": eventually carbon dioxide is left. To progress from one stage to the next, mutations must take place of bacterial families present with another family. The extremely slow process, requiring sometimes hundreds of years, can be speeded up by applying the land farming principle. Often, though, a standstill occurs after a fast start, because mutations are needed. What the ABR-CIS-system does is to add all the necessary microbiological families simultaneously and the breakup occurs then without interruptions. The technique was recently utilized to clean up the Exxon Valdez spill in Alaska. Some limitations, however, do apply: the ambient temperature must lie between 6 and $30^{\circ} \mathrm{C}$; heavy metals are toxic for bacteria, so sufficient nutrients must be available to allow bacterial growth; and free oxygen must be present. Providing it is well the most difficult phase of the operation.

\section{THE ABR/CIS UNDERTAKING}

The technology encompasses conditioning of the sediment on site, to be achieved by furnishing the oxygen that will reactivate and stimulate the aerobic microbiological activity leading to the organic components' microbiological mineralization. This is done by injecting a mixture of water, ABR-bacteria, and conditioner, a carefully prepared blend of natural minerals containing mainly oxides or carbonates (or both). Oxygen present in the minerals can be released rather fast because of the special chemical composition and the large contact surface. The sediment's characteristics, the selected handling, and the physicochemical condition of the waterway determine the CIS dosage.

A special value of the CIS is the progressive and diffuse liberation of oxygen tailored to the oxygen demand, and so is the possibility of good and equal mixing of CIS into the mud. The approach is far more cost efficient than supplying oxygen by compressed air techniques, hydrogen peroxide injection, or nitrate dosage.

Provided the CIS conditions are fulfilled, the following results will be observed, though not necessarily all, nor with the same intensity: de-eutrophication, neutralization of $\mathrm{pH}$, enrichment in oxygen and oxidation, denitrification, mineralization of organic components leading to mud, mass volume decrease, calcium availability for water dwellers such as fish and crustaceans, enrichment of fauna and flora, occasional decrease of water-column turbidity, and decrease of mud cohesiveness.

Conditions for CIS use encompass principally water physicochemistry, mud composition, and seasonal conditions. Reactivation of aerobic biodegradation will yield best results if optimum conditions-in the sediment itself-are attained, such as an oxygen supply that is both very dispersed and available, temperatures well above $20^{\circ} \mathrm{C}$ but not exceeding $40^{\circ} \mathrm{C}$, absence of toxins, specificity, and mutant population since for particular contaminants complete biodegradation without toxin formation must be insured. Effects of the treatment can be observed within a few months and may persist for as long as 2 years.

"4fiff-blends" are injected simultaneously with the CIS, carefully selected on the basis of the indigenous bacterial populations and the micropollutants to be biodegraded.

The ABR/CIS approach is an in situ optimized system that can treat selectively organic aquatic bottoms. Advantages of the system include the environment-protection-aimed breakup of nocive organic matter, economic in situ compaction of the mud, simultaneous treatment of bottom and water column, suppression of dumping ground, and combustion costs.

\section{PROCEDURE AND RESULTS OF THE METHOD}

The application of $\mathrm{ABR} / \mathrm{CIS}$ in a project of microbial dredging/treatment requires identification research to select appropriate microbial population and appropriate injection method, including a treatability/feasibility study; execution of the $4 \mathrm{Sfi} / \mathrm{C} 75^{\mathrm{TM}}$ procedure; and follow-up of the project and eventually identification of further actions to be taken.

\section{SOME CASES}

Contaminated sludge has been treated in the Netherlands at Krimpener-waard. A 150-m-long and $160 \mathrm{~m}^{2}$ sludge area was involved, isolated by means of wooden walls. A volume reduction of $50 \%$ was obtained. Randomly taken sediment samples from canals in Ghent, Belgium showed in all cases bacterial growth that clearly indicated a breakdown of the contaminants through digestion by micro-organisms. With the breakdown of organic constituents set as a function of time, after approximately 14 days $90 \%$ digestion was reached; the microbial activity then stopped, indicating that the breakdown was completed. Volume reduction of the sediment in situ and mineralisation of organic contaminants are related to that microbiological activity.

Part of the heavily polluted (hydrocarbons, tributyltin) fishing harbor of Zeebrugge on the North Sea coast of Belgium was also an area of treatment. Initially, the microbiological activity was very low, with approximately 10,000 colonyforming units (CFU) per gram (dry solid). Instead, after treatment the microorganisms' activity proved high as it stood at a level exceeding 100,000 CFU during the entire 64-week period of monitoring. A biodegradation of $55 \%$ has been reached. Part of another strongly polluted canal, the Zoutegracht (near Zierikzee, the Netherlands) was another site subjected to the ABR-CIS treatment.

\section{Evolution of Organic Pollutants and Biodegradation ${ }^{7}$}

Most PAHs are biodegrading, yet some will increase: this evolution has also been observed in Zoeterwoude (the Netherlands) where sludge was treated. Laboratory experiments show that results are strongly influenced by the nature of the sediments, their characteristics, and by the pollutants' degree of concentration.

The ABR-CIS approach is to be tested in several California locations as well as in New York State, in waterways, basins, and harbor situations. 
Use of indigenous microorganisms for the degradation or destruction of organic contaminants has been acknowledged in relation to coastal oil spills. PCBs are only degraded by anaerobic microorganisms and resulting compounds, in turn, by aerobic ones. Garbaciak reported already 20 years ago a demonstration of the cyclic approach (1992 and 1993) in the Sheboygan River (Wisconsin) but the test could not be considered conclusive because insufficient oxygen delivery did not create real aerobic conditions in the sediments. ${ }^{10}$

\section{CONGLUSION}

Considerable savings can be realized with the ABR/CIS approach because dredging becomes unnecessary, or at least its frequency is greatly reduced. The problems of storage or incineration are cancelled and the foul smells concomitant with the removal of the mud are eliminated. Additionally the method is environment-friendly inasmuch as nature's way is applied; scourges such as eutrophication and algal blooms disappear or at least decrease, and restoration of fauna and flora follows.

Although it is said that man can substantially contribute to lesser fouling of waterways, bays, and inlets by better management of his industries, agriculture and municipal wastes and modern society in industrialized and other countries alike will remain faced with serious threats to the aquatic environment, water column, and bottom.11 Sedimentation occurs in harbors, canals, and rivers and coastal gulfs, inlets, and harbors. As this mud is often deposited in areas with slow water renewal, the oxygen supply to the sediment is small and its low permeability due to the presence of clay minerals and horizontal layering hampers vertical oxygen diffusion, and yet the chemical oxygen demand is high because of dire high proportions of iron hydroxides.

To maintain the navigability of waterways, to prevent flooding at times of spate or heavy rains, they must be dredged. Ocean dumping is a practice that is severely frowned upon nowadays (even though a renewed look is again taken at this

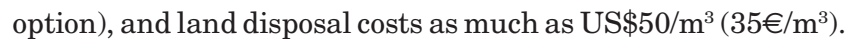
Industrial treatment is likewise quite expensive, a slow process with exceedingly specific methods topped by low efficiency.

In less industrialized but densely populated countries the discomfort, viz. foul smell brought about by dredging operations, generates strong opposition. Yet, the sediment in place may constitute a health hazard.

Microbiological dredging, treatment in situ, and aquatic system normal oxygen balance restoration embodied in the $\mathrm{ABR} / \mathrm{CIS}$ approach appear thence as a method that can be safely used the world around. ${ }^{14}$ It has been, as explained above, successfully used in Belgium and in the Netherlands.

Bioremediation does not usually produce instant gratification, a trait of direct physical intervention. However, the latter approach may strongly disturb such environments as mangroves, marshes, and shorelines with intense biological activity; for these, bioremediation may well be the appropriate prescription. In open coastal systems, microbial injection has not been proven very successful, whereas nutrient addition has enhanced natural degradation. ${ }^{13}$ However, bays and gulfs with narrow access might register highly satisfactory results. Nitrogen fertilizers have been known to speed up the growth of naturally occurring bacteria that degrade petroleum hydrocarbons. The effectiveness and growth of such bacteria could apparently be enhanced by liposomes, which generate physical changes in spilled oil. Liposomes, ball-like structures that trap water inside, are bilayers resulting from the contact of lecithins with water.

\section{ACKNOWLEDGMENT}

The CIS process was originally developed by a Ghent (Belgium) concern, Harbour Engineering Consultants (HAECON), through its subsidiary N-Vironment. The process is now the property of a Swiss company.

\section{LITERATURE GITED}

H. P. Laboyrie. "Disposal options and their environmental impact: disposal on land" Course Dredging and the Environment (Stichtmg Postakademisch Onderwijs, Central Dredging Association, Rijkswaterstaat, 15-17 November, Amsterdam, 1989).

M. Loxham. "Disposal options and their environmental impact by mobiliy of contaminants" ${ }^{1}$ Course Dredging and the Environment (Stichting Postakademisch Onderwijs, Central Dredging Association, Rijtswaterstaat, 15-17 November, Amsterdam, 1989).

A. Dhaese, Invloed van anorganise verontreiniging op de relatie bodem-water-plant (State University, Ph. D. Thesis. Ghent (B), 1977).

B. Malherbe, "Disposal options and their environmental impact "aquatic disposal" Course Dredging and the Environent (Stichtmg Postakademiscb Onderwijs, Central Dredging Association, Rijkswaterstaat, 15-17 November, Amsterdam, 1989).

G. 1. Annokkee, W. J. van Gemert and H. J. van Veen, "Reiniging van baggerslib" (TNO Amsterdam, 86-106, 1986); G. J. Annockee, "Methods used to treat contaminated dredged material" Course Dredging and the Environment (Stichting Postakademisch Onderwijs, Central Dredging Association, Rijkswaterstaaf, 15-17 November, Amsterdam, 1989); W. J. van Gemert. J. Quakcrnaat and H. J. Van Veen. "Methods for the treatment of contaminated dredged sediments" In: V. Salomons and U. Forstncr (eds.), Environmental Management of Solid Waste-dredged Material and Mate Tailings. Springer-Verlag, Berlin, pp. 44-64.

See note 4: G. J. Annokkee.

See note 3 .

C. De Meyer et al. "Experience with in situ ABR-CIS" bioremediatian of sediments in harbours and water-ways" CATS II (Characterization and treatment of contaminated sediments) Antwerp, Belgium, Nov. 15-17, 1993, 3.37-3.42 (1993).

Anonymous 1993. ABR-C1S bioremediation of the Canal Wesieindse Watering at Zoeterweide/the Netherlands (HAECON N.V. and Consult Maatschappij, B.V., Ghent, 1992); J. De Fiaye et al. "Biodegradation experiments of PAH polluted sediments by aeration and with application of inocula" CATS II (Characterization and treatment of contaminated sediments\}, Antwerp, Belgium No. 15-17, 1993, 3.49-3.53.

J. Joziasse et al. 1993. "Bioremediation of contaminated sediments in the Netherlands" CATS II (Characterization and treatment of contaminated sediments), Antwerp, Belgium Nov. 15-17, 1993, 115.

Blasland Bouck Engineers, P.C. and USEPA-Great Lakes Nat. Progr. Off. 1992. Sheboygan River and Harbor Biodegradation Pilot Study Work Plan (Blasland and Bouck Eng., P.C., Milwaukee, Wl, USA); Garbaciak, S., Jr., et al., 1993. "Laboratory and field demonstrations of sediments treatment techniques by the USEPA's assessment and remediation of contaminated sediments (ARCS) program". CATS II "Characterization treatment of contaminated dredged material" Antwerp, Belgium 15-17 Nov. 1993, pp. 3.15-3.24.

J M. Marquenie, W C. De Kock, and P M. Dinneen, 1983. "Bioavailability of Heavy Metals in Sediments". Proceedings of the International Conference on Heavy Metals in ihe Environment. Heidelberg (pp. 944-947. 
J R. Senten and R H. Charlier, 1991. "Heavy metals sediments pollution in estuarine and coastal waters: corrective measures for existing problems" International Journal of Environmental Studies, 37, 79-96.

R. Hoff, 1992. "Bioremediation. A counter-measure for marine oil spill”. Spill Technology Newsletter, 1, 1;A.J. Mearns, 1993. "Appropriate technologies for marine pollution control". Sea Technology, 34, 10, 31-38.

\section{APPENDIX 1}

iPIANC's original name is Permanent International Association of Navigation Congresses; it has been streamlined 2 years ago into International Navigation Association but retained the acronym used for more than a century.

${ }^{i i}$ Charlier, R.H. \& De Meyer, C.F., 1990. Whereto with waterways' and coastal marine sludge?: PIANC [Symposium, Djakarta] Bulletin

iiiDe Meyer, C.F.; Charlier, R.H.; De Vos, K., and Malherbe, B., 1997. Sea Technology, 56, 1, 57-59; Charlier, R.H.and De Meyer, C.F., 2001. Moervaart and Sheboygan River, 57, 6.

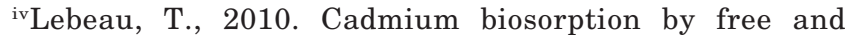
immobilised microorganisms cultivated in a liquid soil extract medium: effects of $\mathrm{Cd}, \mathrm{pH}$ and techniques of culture, Sci Total Environ 291:73-83; Id., 2009, Diatom cultivation and biotechnologically relevant products. Part I: cultivation at various scales. Applied Microbiology and Biotechnology, 60, 612-623; Id., 2009. Diatom cultivation and biotechnologically relevant products. Part II: current and putative products. Applied Microbiology and Biotechnology, 60, 624-632.

vAbramowicz, D.A. 1995. Aerobic and anaerobic PCB degradation in the environment. Environmental Health Perspective, 103, Supplement 5, 97-99; Liu, S.M. and Jones, W.J., 1995. Biotransformation of dichloromatic compounds in nonadapted and adapted freshwater sediment slurries. Applied Microbiology and Biotechnology, 43,725-732; Wilson, S.C. and Jones, K.C., 1993. Bioremediation of soil contaminated with aromatic hydrocarbons (PAHs): a review. Environmental Pollution, 80, 229-249; Safe, S., 1980. Metabolism uptake, storage and bioaccumulation. In: Kimbrough, R. (ed.), Halogenated Biphenyls, Naphthalenes, Dibenzodioxins, and Related Products. Amsterdam: Elsevier, North Holland, pp. 81-107; Seech, A.; O'Neil, B., and Comacchio, L.A., 1993. Bioremediation of sediments contaminated with polynuclear aromatic hydrocarbons (PAHs). In: Proceedings of the Workshop on the Removal and Treatment of Contaminated Sediments. Environment Canada's Great Lakes Cleanup Fund, Wastewater Technology Centre (Burlington, Ontario, Canada).

${ }^{v i}$ Bishop, D.F., 2010. Bioremediation of sediments. Seminar Series on Bioremediation of Hazardous Waste Sites: Practical Approaches to Implementation, 3-1, IP, 3-6.

\section{$\square$ RÉSUMÉ $\square$}

La pollution par des marées vertes pose depuis des décennies de sérieux problèmes aux régions côtières, et aussi à des lacs, et ont des impacts économiques-et physiques_négatifs, particulièrement sur le tourisme. Celui-ci souffre aussi fréquemment de la mauvaise qualité de l'eau. La communication se penche sur ces fléaux. Mais il y a plus. Les côtes, golfes, estuaires et voies navigables, parfois réceptacles de boues, sédiments et déchets polluants ne sont plus à même de remplir le rôle de purificateurs et on en est réduit à draguer ces chenaux et plans d'eau afin de pouvoir les utiliser et de protéger la santé. Ce procédé est onéreux et dégage souvent des odeurs nauséabondes; mais, qui plus est, les matériaux dragués ne peuvent, en principe, être déversés en mer et sont déposés sur des espaces terrestres côuteux et qui pourraient être dévolus à des fins autrement utiles. Des démarches nouvelles sont donc indiquées et parmi elles la bioremédiation est prometteuse et conforme aux procédés naturels. L'article la discute, avertit qu'elle n'est pas une solution miracle, que certains composés y résistent, mais que toutefois elle s'est avérée efficace dans de nombreux cas qui géographiquement ont fait la preuve des avantages de la méthode lors d'essais et d'applications entre autres aux Pays-Bas, en Belgique et aux Etats-Unis d'Amérique.

\section{$\square$ ABSTRAKT $\square$}

Wraz z postępem opinia, iż rzeki, morza i oceny oczyszczają się same przestała być aktualna. Proces ten ma dużo bardziej złożony charakter. Zanieczyszczenie dróg wodnych, spowodowało, iż wiele z nich nie może być wykorzystywanych do transportu wodnego. Stosowane tradycyjne metody oczyszczania, polegające na usunięciu zanieczyszczeń szlamowych z dna z wykorzystaniem specjalistycznego sprzętu, są drogimi metodami, ponadto nie jest to dobre rozwiązanie, gdyż są one składowane na lądzie, a dostępność obszarów lądowych nie jest nieograniczona. Zagadnienia bioremediacji in situ (w miejscu) gromadzą obecnie rosnącą liczbę ekspertów. W pasie wybrzeży i na rzekach prowadzone są różne działania mające na celu ograniczenie szkód spowodowanych przez "zielone pływy" i inne zanieczyszczenia. W publikacji dokonano przeglądu i oceny prowadzonych w Europie i USA badań możliwości zastosowania bioremediacji in situ. Oczyszczanie wód ze szlamu jest koniecznością ze względu na ograniczone obszary jego składowania, ale również by chronić życie i zdrowie ludzi, zwierząt i roślin.

Dokonano znaczących postępów w dziedzinie bioremediacji, nie ograniczając ich do zagadnień z dziedziny hydrologii. Istnieje jednak kilka często pojawiających się związków, które pozostające odporne na tą metodę oczyszczania. Pilotowe projekty badań prowadzone są obecnie w krajach europejskich i USA.

\section{$\square$ SAMENVATTING $\square$}

De dumping van gebaggerd slib op land is een kostelijke praktijk met dikwijls milieu nadelige gevolgen. Biologische bewerking zoals in België, Nederland en de Verenigde Staten van America experimenteel doorgevoerd schijnt een veelbelovende aanpak. Deze bijdrage beschrijft de methode, ABR/CIS van de voormalige firma HEACON die getest werd in de Moervaart, Zierickzee en de gelijkaardige proeven in Sheboygan (Staat Wisconsin, VSA) en de Hudson Rivier nabij New York Stad. 
Reproduced with permission of the copyright owner. Further reproduction prohibited without permission. 